\title{
A inserção do "Brasil"" nos quadros da economia-mundo capitalista no período 1550-c.1800: uma tentativa de demonstração empírica através da cadeia mercantil do açúcar ${ }^{2}$ \\ Pedro Antonio Vieira ${ }^{3}$
}

\section{Resumo}

Utilizando o conceito de cadeia mercantil, o artigo procura mostrar que o desenvolvimento da agroindústria do açúcar no Brasil colonial criou conexões entre produtores, comerciantes e consumidores de muitas mercadorias na América, na África, na Europa e na Ásia, contribuindo, portanto, para o desenvolvimento da economia-mundo capitalista, da qual a produção açucareira na colônia era uma parte. Para sustentar a tese, busca-se evidenciar que atividades normalmente vistas como autônomas, como é o caso da produção para o mercado interno e o tráfico de escravos, são, de fato, parte da cadeia mercantil do açúcar.

Palavras-chave: Brasil - Economia colonial; Economia-mundo; Cadeia mercantil global; Açúcar.

\section{Abstract \\ The insertion of "Brazil" in the capitalist world-economy between 1550 and c. 1800: an attempt at empirical demonstration through the sugar commodity chain}

Using the commodity chain concept, this paper demonstrates how the development of the sugarcane industry in Brazil during the colonial period created links between producers, merchants and consumers of many commodities in America, Africa, Europe and Asia, thus contributing to the development of a capitalist world-economy in which the production of sugar in the colony was a part of. As a basis to this thesis, it is claimed that activities which are normally regarded as autonomous, such as the production for internal markets and the slave trade, are, in fact, part of the sugar commodity chain.

Key words: Brazil; Colonial economy; World-economy; Sugar-cane; Global commodity chain. JEL N56, Q17, F59.

O Brasil é apanhado e arrastado passivamente no vórtice daquela luta, e sua evolução econômica será função de grandes acontecimentos mundiais que se compreendem e explicam apenas no cenário universal e em conjunto com a história geral da Humanidade. (...) Não há mais, verdadeiramente, no mundo

(1) Brasil está entre aspas porque este é o nome de uma entidade política que só veio a existir muito mais tarde. No período aqui analisado, este termo, que empregamos por comodidade, de fato, designa as várias áreas da colônia portuguesa da América.

(2) Trabalho recebido em março de 2009 e aprovado em setembro de 2009. Uma primeira versão deste artigo foi apresentada no II Colóquio Brasileiro em Economia Política do Sistema-Mundo, realizado em Florianópolis em 2008. O autor agradece ao Departamento de Sociologia da Universidade de Maryland/EUA as facilidades oferecidas para que, durante seu estágio pós-doutoral, pudesse ampliar a pesquisa bibliográfica.

(3) Professor do Departamento de Economia da Universidade Federal de Santa Catarina (UFSC)/ Coordenador do Grupo de Pesquisa em Economia Política dos Sistema-Mundo, Florianópolis, SC, Brasil. E-mail: pavieira@cse.ufsc.br; pavieira60@gmail.com.

Economia e Sociedade, Campinas, v. 19, n. 3 (40), p. 499-527, dez. 2010. 
Pedro Antonio Vieira

\begin{abstract}
contemporâneo, história econômica deste ou daquele país, mas unicamente a de toda a humanidade (Caio Prado Jr.).

O crescimento quantitativo [na produção de açúcar] foi o único consentido pela divisão internacional do trabalho e pela escravidão (Ruy Gama).
\end{abstract}

O problema vital é o custo dos bens de produção importados, o cobre e o negro em especial (Alice Canabrava).

Porque tudo o que é doce, ainda que imundo, deleita (Antonil).

\title{
Introdução
}

Este texto tem um objetivo modesto: apresentar evidências de que, em função da quantidade, dos agentes - privados e estatais - envolvidos e do emprego do trabalho escravo, a produção, a comercialização e o consumo do açúcar a partir do século XVI acabaram por constituir aquilo que recentemente se passou a chamar "cadeia mercantil global", contribuindo assim para a formação da economia-mundo capitalista. Para dar conta deste objetivo vamos reconstruir a cadeia mercantil do açúcar no período 1550-1800, o que exige identificar e localizar espacialmente as atividades necessárias para que o açúcar fosse produzido e consumido. Nesta perspectiva, quando nas primeiras décadas do século XVI, o estado português, apoiado por capitalistas de várias nacionalidades, passou a fabricar açúcar na colônia americana, estava, de fato, efetivando um deslocamento de parte da cadeia - plantio da matéria-prima e produção do açúcar - para as possessões lusitanas no continente americano. O sucesso deste deslocamento repercutiu em toda a cadeia, diminuindo os preços e aumentando o consumo, como também atraindo a atenção de outros estados e capitalistas para o negócio do açúcar, incluindo-se o tráfico de escravos, o que, por sua vez, gerou novos reajustamentos dos agentes privados e estatais envolvidos. Devemos destacar que a descrição e análise destes movimentos não será sequer iniciada no presente texto. Nossa intenção é simplesmente desenhar a cadeia mercantil do açúcar para mostrar que, ao colonizar suas terras americanas através da produção de açúcar, Portugal inseriu este território no processo de formação da economiamundo capitalista.

Esta interpretação da colonização pode ser vista como uma derivação da linha de pesquisa dos clássicos da historiografia econômica brasileira. Assim, se para Celso Furtado (1995, p. 5) esta colonização era "um episódio da expansão comercial da Europa", para Caio Prado Júnior (2008, p. 29, grifos nossos) "no seu conjunto, e vista no plano mundial e internacional, a colonização dos trópicos toma o aspecto de uma vasta empresa comercial, (...) destinada a explorar os recursos naturais de um território virgem em proveito do comércio europeu”, o que configuraria, para este autor, o sentido da colonização. Por sua vez, Fernando Novais (2005, p. 41, grifos nossos) propõe que a colonização adquire sentido 
quando vista como "uma peça no conjunto de mecanismos que, promovendo a acumulação originária, tendiam a possibilitar a superação dos entraves institucionais e econômicos que ainda perturbavam a expansão do capitalismo moderno europeu." Vale a pena registrar o fato de Novais assinalar que Caio Prado não pôde fazer esta mesma vinculação porque ficou preso "à tradição da historiografia brasileira, sempre menos voltada para as vinculações da história do Brasil com a história geral da civilização ocidental" (Novais, 2005, p. 40).

$\mathrm{Na}$ perspectiva que adotamos, o sentido da colonização não seria a aceleração da acumulação primitiva e da acumulação propriamente capitalista, mas a formação de um sistema social histórico específico, o moderno sistemamundo, sinônimo de economia-mundo capitalista. No artigo citado, publicado pela primeira vez em 1969, o próprio Novais chegou muito perto desta formulação quando vinculou a colonização "ao processo histórico de formação do capitalismo moderno, à transição do capitalismo comercial para o industrial (capitalismo pleno)" (Novais, 2005, p. 40). Mais tarde, em artigo publicado em 1984 - ou seja, dez anos depois do lançamento de "O Moderno Sistema Mundial" por Immanuel Wallerstein -, o mesmo autor escreveria que "o sistema colonial era parte integrante e articulada nessa estrutura global - a que Wallerstein chamou 'Modern World-System'" (Novais, 2005, p. 187-188). Não obstante o registro, Novais manteve interpretação de 1969, segundo a qual o verdadeiro capitalismo se inicia com a Revolução Industrial Inglesa do final do século XVIII:

Os mecanismos de fundo - a transição para o capitalismo -, no seu processo essencialmente contraditório, engendravam pois tensões que, a partir de um certo momento (segunda metade do século XVIII), desencadeiam conflitos, obrigando a reajustamentos no todo e nas partes (Novais, 2005, p. 189, grifo nosso).

Sem dúvida, este autor defende que na segunda metade do século XVIII ainda estava em curso a transição para o capitalismo. Na citação, vemos também que Novais supõe um todo, o qual, não obstante, permanece indefinido. Para nós, este todo é a economia-mundo capitalista, composta por um subsistema político formado pelo conjunto de estados nacionais - e por subsistema econômico, constituído pelas cadeias mercantis que atravessam o globo terrestre e que admitem diferentes processos produtivos, relações de trabalho e meios de produção.

Além de Novais, Luis Felipe Alencastro e Pedro Puntoni são historiadores que empregam a expressão "economia-mundo". Alencastro (2000) parece admitir explicitamente a economia-mundo como o sistema social histórico no interior do qual se desenvolveu a economia do Atlântico Sul, a qual, por sua vez, gira em torno do comércio de escravos. No entanto, ao usar a expressão "sistema" para referir-se às relações econômicas, políticas e culturais entre Brasil e África, implicitamente está conferindo a estas relações uma autonomia e 
autodeterminação que elas, como procuraremos mostrar, não possuem. Já Puntoni (1999), além de fazer várias referências à obra de Wallerstein, também utiliza o termo "economia-mundo". Todavia, nenhum dos dois faz qualquer tentativa de mostrar ou de aclarar o que entendem por economia-mundo. E talvez por se manterem ainda na posição de historiadores, não estão interessados em assumir os desdobramentos metodológicos da assunção da economia-mundo enquanto unidade de análise, como, por exemplo, proceder a certas generalizações e questionar a divisão interno-externo. ${ }^{4}$ Assim, ao analisar as lutas entre diferentes grupos holandeses pela condução dos negócios e da política externa das Províncias Unidas, Puntoni (1999) afirma que as motivações para a criação da Companhia das Índias Ocidentais eram internas, ${ }^{5}$ mesmo quando a disputa se dava em torno do controle do comércio colonial. Agregue-se que a criação desta empresa em 1621 foi, segundo o próprio autor, a solução encontrada pelos Estados Gerais para superar a divisão que ameaçava a própria existência da República e que permitiria, simultaneamente, combater a Espanha através da guerra e do controle do comércio de suas colônias. Se os problemas que estão sendo enfrentados são claramente globais ${ }^{6}$ e envolvem conflitos entre estados, por que continuar defendendo que os móbiles são internos? ? $^{7}$ Esta insistência, pensamos, decorre da não adoção da economia-mundo como unidade de análise.

Acioli e Menz (2008) assumem esta unidade de análise para mostrar que o uso de mercadorias asiáticas no tráfico de escravos envolvia, em uma mesma rede, Europa, América, África e Ásia. Poderíamos dizer que, através da explicitação das ramificações da cadeia mercantil do açúcar, o presente texto se soma aos esforços destes dois historiadores.

Entre os historiadores brasileiros que podem ser considerados refratários a uma visão sistêmica, podemos citar João Fragoso e Manolo Florentino, cujo livro conjunto $^{8}$ tem como principal objetivo mostrar que, ao contrário do que afirmavam Furtado, Caio Prado e Novais, a economia colonial tardia (1790-1830) "desfrutava de uma relativa autonomia em face das flutuações do mercado internacional" e

(4) Também é possível que a resistência dos historiadores à teoria e às generalizações os impede de admitir a existência de um sistema tão abrangente como a economia-mundo. Adotar a perspectiva da "Análise dos Sistemas-Mundo" implicaria ultrapassar as fronteiras da história enquanto disciplina acadêmica, o que tem suas consequências, não obstante, como adverte Abu-Lughod (1989, p. viii): "original insights are often possible when scholars risk crossing disciplinary lines".

(5) "A disputa que resultara na fundação da Companhia fazia-se antes na própria Holanda; seus móbiles eram internos" (Puntoni, 1999, p. 49).

(6) Devemos lembrar que a Companhia das Índias Orientais (VOC), fundada em 1600, e que provavelmente serviu de modelo para a WIC, já vinha cumprindo as mesmas funções naquela região do globo.

(7) Talvez o autor esteja usando "interno" para designar agentes localizados ou domiciliados num determinado território ou jurisdição, mesmo que sua área de atuação seja o mercado mundial.

(8) Trata-se da obra "O Arcaísmo como projeto: mercado atlântico, sociedade agrária e elite mercantil em uma economia colonial tardia, Rio de Janeiro, c. 1790-1840”. Ver Referências bibliográficas. 
que, em grande parte, "a reprodução desta estrutura relativamente autônoma" (Fragoso; Florentino, 2001, p. 56) se devia ao fato dos comerciantes de grosso trato (a classe mercantil residente) controlarem os elementos necessários à sua reprodução: mão de obra escrava, terras e víveres. Em nossa opinião, este tipo de conclusão decorre da unidade de análise escolhida, que, no caso dos autores, é a economia ou sociedade colonial. Ora, uma vez escolhida (consciente ou inconscientemente), ou melhor, definida, uma unidade de análise - indivíduo, família, empresa, estado-nação, economia-nacional ou outra qualquer - sempre parecerá ser dotada de autodeterminação e de objetivos próprios, o primeiro dos quais é sua autopreservação e reprodução ampliada. No entanto, isto não quer dizer que esta autorreprodução seja determinada "internamente" à unidade em questão. Pense-se, por exemplo, em uma pessoa que vende sua força de trabalho a uma empresa capitalista. Sem dúvida, sua motivação é a obtenção da renda que permitirá comprar os meios de subsistência necessários à sua sobrevivência. No entanto, ao perseguir este objetivo que lhe é próprio, esta pessoa se insere no circuito de reprodução do capital. Sem muitos questionamentos aceitamos que, para entendermos o modo de vida, os valores, e as possibilidades deste trabalhador, precisamos estudar, como fez Marx, a lógica da acumulação capitalista. Temos então duas lógicas ou conjunto de interesses: a do indivíduovendedor da força de trabalho e a do processo mais amplo no qual ele se insere e ao qual serve. Neste caso, dificilmente diremos que o indivíduo é autônomo. Já preconizar que ele goza de uma autonomia relativa é dizer muito pouco, pois este é um suposto de qualquer relação humana.

A questão central nos parece ser outra e diz respeito à escolha e explicitação da unidade de analise. Como dito acima, se ampliamos o escopo da unidade de análise, podemos passar do indivíduo para a família, para a classe, para a economia-nacional e para a sociedade mundial. Enquanto pudermos fazer esta ampliação e identificarmos relações externas à unidade considerada, ou melhor, enquanto a reprodução desta unidade depender de intercâmbios com agentes externos a ela, não estamos diante de uma unidade autodeterminada. O movimento cessa quanto chegamos à unidade maior, envolvente, autocontida, que é o sistema histórico e que denominamos economia-mundo. Nesta ordem de ideias, a dicotomia local-sistêmico ${ }^{9}$ ou interno-externo ${ }^{10}$ perde consistência, pois o espaço

(9) Toda atividade (econômica, política, cultural etc.) é sempre levada a cabo em um espaço concreto, determinado e, inclusive, mensurável. Portanto, quando vista em si mesma, toda atividade é sempre local. Porém, se for possível inserir esta atividade em um processo que se estende para além deste espaço imediato, então ela já deixou de ser exclusivamente local. Se a extensão deste processo é global, aquela primeira atividadde só pode ser considerada local se a isolamos do processo em que se insere. É por este motivo que afirmarmos que, numa perspectiva sistêmica, a dicotomia local-sistêmico se dilui.

(10) Em seu estudo da cadeia mercantil global da cocaína, Gootemberg (2006, p.322) conclui que o enfoque holístico possibilitado pelo conceito de cadeia mercantil "nos ajuda a superar as tradicionais divisões entre fatores internos e externos e entre fatores econômicos e não econômicos na história da América Latina, binaridades compatilhadas pelas perspectivas neoclássica e da dependência". 
da análise se estende para os encadeamentos a jusante e a montante da unidade considerada, o que obriga o pesquisador a ampliar seu campo de estudo para todo este conjunto de relações ou intercâmbios, independente da jurisdição política em que se localizem.

Na medida em que explicita as dependências mútuas entre produtores, comerciantes e consumidores de todos os insumos necessários à produção de uma mercadoria, o conceito de cadeia mercantil parece ser particularmente útil para a verificação empírica tanto da extensão espacial como da inserção (ou não) de um determinado processo ou atividade econômica em um processo ainda maior.

A seguir (seção 1) enfocaremos sumariamente o conceito de cadeias mercantis dentro da perspectiva da Economia Política dos Sistemas-Mundo. Na seção 2 repassaremos as várias etapas da produção do açúcar para identificar e localizar espacialmente seus componentes, cuja visão de conjunto nos será dada pelo desenho da cadeia mercantil. Na última seção apresentamos nossas considerações finais.

\section{As cadeias mercantis como expressão ou concretização da economia-mundo}

Uma vez tomada a decisão de adotar a economia-mundo como unidade de análise relevante para estudar as mudanças sociais estruturais, coloca-se a necessidade de compreender este sistema histórico. Para tanto, vamos assumir a construção conceitual e histórica feita pelo seu criador, Immanuel Wallerstein, para quem: "[N]o final do século XV e começo do XVI, nasceu o que poderíamos chamar de uma economia-mundo europeia" (Wallerstein, 1999, p. 21). Trata-se de uma única entidade econômica, que em seu espaço convive com diferentes formas de entidades políticas (império, cidades-estados, nações-estado), sendo maior que qualquer uma delas, e por isso constitui-se num "sistema mundial". Ainda nas palavras do autor:

E é uma "economia-mundo" devido a que o vínculo básico entre as partes do sistema é econômico, ainda que em certa medida seja reforçado por vínculos culturais e eventualmente, como veremos, por arranjos políticos, incluindo estruturas confederativas (Wallerstein, 1999, p. 21).

Como se concretiza a economia-mundo? Ou ainda, qual a extensão ou o território de uma economia-mundo? A concretização e a extensão de uma economia-mundo é medida pela variedade e extensão de suas redes de produção e troca que, em linguagem mais técnica, Wallerstein e Hopkins denominaram "cadeias mercantis" (commodity chains). ${ }^{11}$ Com este conceito, os autores designam "processos produtivos interligados que têm cruzado múltiplas fronteiras e que sempre apresentaram dentro deles diferentes formas de controle do trabalho"

(11) In "Commodity chains: construct and research". Ver Referências bibliográficas. 
(Wallerstein; Hopkins, 2000, p. 221). Mais especificamente, uma cadeia mercantil é composta por todas as fases e/ou processos necessários à produção e comercialização de uma mercadoria, desde seus insumos até o consumo final.

As cadeias mercantis constituem uma peculiar divisão mundial do trabalho. O conceito de divisão do trabalho é um dos pilares de toda a argumentação de Wallerstein, uma vez que é precisamente a existência de diferentes atividades (a divisão técnica), em diferentes regiões (divisão espacial) realizadas por diferentes grupos étnicos (divisão étnica) com diferentes remunerações (divisão de renda) que permite o florescimento da economia-mundo europeia, a qual, por definição, desde o século XVI inclui as colônias ibéricas na América (Wallerstein, 1979, p. 142). Um aspecto da divisão técnica do trabalho é o emprego de diferentes formas de controle do trabalho (expressão que Wallerstein usa para designar o que na sociologia conhecemos por "relações de trabalho"), as quais implicam e, efetivamente, dão lugar a estratificações políticas, econômicas e sociais, "que por sua vez tiveram diferentes consequências políticas para os 'Estados', quer dizer, para as arenas da ação política" (Wallerstein, 1999, p. 118).

Por fim, o conceito de cadeia mercantil impede separar o que a busca do lucro e do poder uniram, isso porque obriga a situar, num mesmo continuum, governantes, negociantes, consumidores e trabalhadores dos vários espaços ou jurisdições políticas nas quais estão localizadas as atividades em que se decompõe o processo de produção, comercialização e consumo de uma mercadoria. Nesta perspectiva, o que é visto como um sistema - que significa autonomia - passa a ser um subsistema, ou seja, parte de um sistema maior, este sim autocontido. Os historiadores costumam dizer que o sistema escravista teria dois polos, o Brasil e a África. ${ }^{12}$ Com o conceito de cadeia mercantil, este "sistema" passa à condição de subsistema ou de parte da cadeia mercantil do açúcar, que por sua vez é um componente da economia-mundo capitalista.

Para demonstrar que já no século XVI existia uma economia-mundo capitalista, Wallerstein e Hopkins partem da seguinte indagação: em que medida os processos produtivos das diferentes jurisdições políticas e áreas geográficas eram partes integradas de uma complexa divisão do trabalho em escala mundial, marcada por fases de expansão e contração? (Wallerstein; Hopkins, 2000). Nosso objetivo é muito mais modesto. Queremos apenas mostrar que a produção e o consumo do açúcar integraram processos comerciais e produtivos que ocorriam no

(12) "Sucede que a exploração da agricultura escravista pressupunha o comando dos dois polos do sistema: os portos africanos e as zonas escravistas americanas" (Alencastro, 2000, p. 236). Afirmações como esta olvidam que toda produção é inútil se não for vendida. Esquecem também que um dos polos do processo produtivo de qualquer mercadoria é seu consumo. No caso do açúcar, a agricultura escravista tem outro polo na Europa, onde o produto é refinado e consumido. 
Brasil, na Europa, na África e na Ásia. Para isso, através do desenho da cadeia mercantil do açúcar, vamos inserir no mesmo campo visual os encadeamentos a jusante e a montante da agroindústria açucareira localizada na colônia portuguesa da América. Pensamos que esta visão de conjunto fornecerá uma boa percepção das relações entre atividades normalmente vistas separadamente.

Ficará para a continuidade da pesquisa a identificação das mudanças espaciais e temporais havidas na cadeia mercantil do açúcar no período estudado, tanto em termos de sua localização como das relações de poder entre os vários componentes da cadeia, como, por exemplo, entre produtores e comerciantes. ${ }^{13}$

\section{A cadeia mercantil mundial do açúcar}

Nesta seção vamos apresentar os primeiros resultados de nossa pesquisa e oferecer as evidências de que, de fato, a produção e a comercialização do açúcar constituíram uma cadeia mercantil mundial, o que exige que mostremos a extensão espacial dos insumos (instrumentos e equipamentos, matéria-prima e força de trabalho) e do produto.

Com este fim, vamos primeiramente (subseção 2.1) mostrar os encadeamentos para trás provocados pela obtenção e utilização da força de trabalho dos povos africanos escravizados. Em seguida, na subseção 2.2, relacionaremos e identificaremos a procedência espacial dos instrumentos de trabalho utilizados nas várias etapas em que se pode dividir a produção do açúcar: plantio, colheita, transporte da cana-de-açúcar e a fabricação ${ }^{14}$ propriamente dita. Na subseção 2.3 trataremos da questão do refino e comercialização do açúcar.

\subsection{Os encadeamentos criados pela obtenção da força de trabalho}

Durante boa parte do século XVI predominou na produção açucareira o trabalho forçado dos nativos. Sua substituição por trabalhadores escravos africanos se deu ao longo de meio século, de modo que nas primeiras décadas do século XVII havia se afirmado claramente esta forma de suprimento da força de trabalho. ${ }^{15}$

(13) Muitas das possibilidades teóricas e empíricas das cadeias mercantis globais podem ser encontradas em Gereffi e Korzeniewicz (1994) e também em Topik; Marichal e Frank (2006). O primeiro livro apresenta os textos seminais de Wallerstein e Hopkins, além de um grande número de estudos de cadeias mercantis atuais. O segundo concentra-se em cadeias mercantis latino-americanas desde o período colonial, entre as quais três estudos de produtos brasileiros: o café, o cacau e a borracha. O açúcar é estudado, mas somente para o período 1850-1950. Comerlatto e Lins (2008) fazem uma aplicação do conceito à indústria moveleira de São Bento do Sul.

(14) Em Gama (1983) e Antonil (1996) é apresentado em detalhes o processo de trabalho nos engenhos coloniais.

(15) Para uma discussão das motivações e do ritmo da transição do emprego de escravos nativos para escravos africanos, ver Schwartz (1988). 
A solução para a demanda de força de trabalho através da importação de escravos da África transformou o tráfico de escravos no principal esteio da produção açucareira e estendeu a cadeia mercantil do açúcar não só para a África, mas para todos os espaços de onde provinham os equipamentos, mercadorias e pessoas envolvidas na obtenção continuada dos trabalhadores escravizados. A obtenção dos cativos na África pelos portugueses, mas não só por eles, se fez por meio da guerra e do comércio (Alencastro, 2000) e mobilizou recursos monetários, mercadorias e homens de várias partes do mundo. ${ }^{16}$ Neste sentido, pelas especificidades das atividades necessárias à escravização em território africano, ao transporte e à reprodução diária nos locais de negociação, nos entrepostos e no destino final, sem dúvida o comércio de escravos gerou circuitos comerciais de grande monta e ao longo dos quatro cantos do mundo. Por isto, é quase impossível exagerar as mudanças econômicas, políticas e culturais que o suprimento de escravos para a produção açucareira provocou no mundo todo entre os séculos XVI e XIX. Não obstante esta inegável grandeza, a força de trabalho escrava era um insumo para a produção de açúcar, e todas as demais atividades - econômicas ou não - destinadas ao fornecimento desta força de trabalho estão completamente inseridas na cadeia mercantil do açúcar. ${ }^{17}$ Nesta perspectiva, para usar a expressão do mesmo Alencastro, esta força de trabalho era uma "mercadoria ancilar". Em suma, todos os negócios que ela cria ou que se criam em torno a ela, são, em última instância, uma criação da mercadoria para qual ela é um meio, um insumo: o açúcar.

Importa observar que ao longo dos quatro séculos (1440-1850) em que o comércio de escravos prosperou no Ocidente associado à produção do açúcar, foram se alterando (e mesmo alternando) os processos, agentes externos e internos à África, ${ }^{18}$ os meios (guerra, comércio, etc.) os locais de origem e de destino das pessoas escravizadas, ${ }^{19}$ e também os bens envolvidos nos intercâmbios entre

(16) Ainda segundo Alencastro, João Rodrigues Coutinho, que adquiriu o asiento para traficar escravos em Angola (onde também foi governador), "antes de deixar a Europa (...) encomendou em Hamburgo navios e ferragens destinadas a Luanda. Do Prata e do Panamá, onde vivera fazendo negócios com escravos e gado, tencionava trazer 2500 cavalos para formar companhias de cavalaria...” (2000, p. 80).

(17) A inserção do tráfico de escravos na cadeia mercantil do açúcar transparece na alegação dos procuradores do Estado do Brasil (mais exatamente, Bahia, Pernambuco e Rio de Janeiro) e de Angola contra a venda de escravos à América Espanhola pela Companhia de Cachéu e Cabo Verde, que "aumentaria os preços dos escravos no Brasil, a quebra de sua produção agrícola, o declínio da navegação e das rendas das alfândegas do Reino" (Alencastro, 2000, p. 329).

(18) Por exemplo, quando a Companhia das Índias Ocidentais monopolizou o tráfico de escravos para o Brasil, os portugueses continuaram controlando a obtenção de escravos no interior e seu transporte até a costa, sendo obrigados a vendê-los aos holandeses. Quando em 1662 a Coroa espanhola voltou à política dos asientos, os novos asientistas subcontrataram a Companhia para fornecer os escravos (Puntoni, 1999).

(19) De 1450 a 1550, da região da Alta Guiné para a Metrópole Portuguesa e Ilhas Atlânticas; daí pra frente, da África Central para o Novo Mundo (Alencastro, 2000, p. 113). Em relação aos cativos levados para a Bahia, segundo Schwartz (1988, p. 282), "no século XVI predominaram os povos da Senegâmbia, no XVII, os de Angola e Congo, e no XVIII, da Costa da Mina e do golfo de Benin". 
escravizadores, comerciantes e utilizadores de escravos. Para os fins do presente texto, vamos nos ater às mercadorias, agentes e regiões envolvidas no tráfico de escravos para a colônia portuguesa da América. A este respeito, Alencastro (2000) chama atenção para os seguintes pontos:

(1) O escambo de escravos encadeia a oferta de uma série de outros produtos africanos, que os próprios escravos transportavam quando eram trasladados de seus povoados de origem para os entrepostos internos e para os portos. ${ }^{20}$ Assim, o interior africano se ligava aos circuitos comerciais mundiais como, aliás, o próprio Alencastro observa. ${ }^{21}$

(2) A esta oferta correspondia uma demanda variável (em função do momento, agentes envolvidos, espaço geográfico) e bastante diversificada de bens produzidos fora da África: manufaturas europeias e asiáticas e produtos brasileiros: zimbos, farinha de mandioca, cachaça, tabaco, cavalos, fubá de milho, marmelada, peixe seco e salgado, queijos, louça de barros.

No caso específico dos produtos oriundos da colônia portuguesa na América, Alencastro informa que madeira de construção, telhas, alvenaria e ferramentas costumavam ser exportados para Luanda e Benguela.

Portanto, a cadeia mercantil do açúcar se espalhava pelos quatro cantos do mundo. Vejamos com mais detalhes como se dava esta articulação espacial. Comecemos pela própria colônia.

\section{Conforme Alecanstro (2000, p. 361),}

desde o final dos anos 1620, Santos já exportava para o Norte da Colônia, ${ }^{22}$ e para Angola, trigo, açúcar, mantimentos, algodão em rama, panos tecidos e ferro fundido. Existia, portanto, uma oferta de produtos regionais - limitada em volume mas variada em mercadoria - que desembocava no porto vicentino.

Não obstante, a farinha parece ter sido o principal produto local a compor a cesta de mercadorias que eram trocadas por escravos. Ainda segundo o mesmo autor, "no primeiro quartel do século XVII (...) o produto brasileiro de escambo afora a prata peruana contrabandeada - era quase sempre a mandioca" (Alencastro, 2000, p. 251), o que sugere a existência de um "ciclo da mandioca", que teve seu pico entre 1590-1630. Produzida em terras fluminenses e em São Vicente, a farinha anualmente exportada para Angola, calcula este autor, chegava a 680 toneladas, sendo vendida por um preço quatros vezes maior. Os lucros

(20) Algumas destas mercadorias: marfim, cera de abelha (no Brasil, muito usada na fabricação de velas), peles, almíscar, cobre, ouro, goma, azeite de palma (Alencastro, 2000, p. 114).

(21) "Todos esses fluxos levavam o comercio continental de longa distância e as trocas marítimas a se acoplarem às estruturas aldeãs de consumo doméstico na África Ocidental e Central” (Alencastro, 2000, p. 115).

(22) Lapa (1968) informa que o suprimento das naus da Índia aportadas em Salvador frequentemente era atendido por São Vicente, que enviava arroz, farinha de trigo, feijão e frutas. 
transformaram os agricultores fluminenses em senhores de engenho, o que mostra como uma mudança social interna se articula ou resulta das vantagens da inserção em uma cadeia mercantil mundial.

Alguns donos de engenho produziam farinha para comprar escravos. No caso do Engenho Sergipe do Conde, em 1607, seu proprietário instrui o feitor para que não deixe de "mandar fazer as mais farinhas que puderem fabricar, para com elas resgatar escravos em Angola." (Apud Ferlini, 2003, p. 183). Alencastro (2000, p. 91) também constatou que "jesuítas da Bahia exportavam mandioca [ou seria farinha? $]^{23}$ para os missionários de Angola em troca de escravos."

Acioli e Menz (2008, p. 50) fazem a seguinte observação a respeito da relevância da farinha no tráfico de escravos:

É possível que a importância da farinha neste período explique-se pelo próprio crescimento e consolidação do tráfico negreiro em Angola; quantidades inusitadas de cativos eram amontoadas no litoral à espera do embarque, excedendo a capacidade de produção de alimentos local; além disso, a importância do comércio de farinha nesta década deveu-se, muito provavelmente, a uma crise de abastecimento que se abateu sobre Angola com a seca de 1614-1617. Finalmente, uma parte expressiva - talvez $1 / 4$ - destes alimentos era consumida na própria viagem, pela equipagem e pelos escravos embarcados.

Outro gênero genuinamente brasileiro que teve a produção muito estimulada por sua incorporação à cadeia mercantil do açúcar foi a aguardente de cana, que os traficantes brasileiros passaram a intercambiar por escravos por volta de 1650. O sucesso foi tão grande que, por sugestão do Conselho Ultramarino, em 1679 a Coroa proibiu por dez anos a importação e o consumo em Angola (Curto, 2004). ${ }^{24}$

Por volta da década de 1690 os grupos interessados em suspender a proibição $^{25}$ argumentam que esta bebida era a principal mercadoria trocada por escravos nos sertões do Congo e nos Dembos (Alencastro, 2000, p. 319). Curto (2004) diz que embora dispondo de um produto muito desejado, os traficantes brasileiros careciam de tecidos europeus e asiáticos, que eram os itens mais procurados na Africa Central e que os traficantes portugueses ofereciam desde o início do tráfico em Angola. Para ele (Curto, 2004, p. 98), na década de 1760, entre 27 e 40,5\% dos 82.911 escravos deportados de Luanda foram trocados por cachaça. Tendo comparado os preços e volumes da cachaça exportada para Angola

(23) Alencastro parece usar mandioca e farinha como sinônimos. Assim, na página 91 diz que parte do soldo das tropas do governo-geral da Bahia era pago com farinha-da-terra. Já na página 92, escreve que, também na África, a "mandioca passa a ser usada no pagamento de soldados".

(24) Ferreira (2001) chega a afirmar que esta bebida teve como efeito mais importante transferir para os negociantes brasileiros o controle sobre o tráfico de escravos.

(25) Mas a "aguardente da terra" continuou chegando à África, contrabandeada, inclusive por altas autoridades, como o Governado de Angola João da Silva e Souza entre 1680-84 (Alencastro, 2000). 
com os preços dos escravos, Acioli e Menz (2008, p. 52, grifo nosso) concluíram que com esta bebida seria possível pagar apenas "a compra de 579 escravos na costa da África, o equivalente a uns 13\% do total exportado por Angola (estimado em 4.619 escravos anuais). O restante dos escravos era comprado por produtos asiáticos e europeus."

Em que pese a polêmica, a cachaça foi usada em grande quantidade na troca por escravos, o que estimulou sua produção, beneficiando todos os envolvidos na cadeia mercantil desta bebida: senhores de engenho, plantadores de cana, ferreiros, caldeireiros, oleiros, transportadores, comerciante e o fisco. Em outras palavras, estimulou a "economia local". Quantos às áreas de origem, como estava associada aos engenhos, nas décadas finais do século XVII, Bahia exportava $61 \%$, Pernambuco $26 \%$ e Rio de Janeiro $12,5 \%$, percentual que vai crescer na seguinte centúria, chegando a $53 \%$ do total descarregado em Luanda em 1760, ao mesmo tempo em que recebia (o porto carioca) $43,5 \%$ dos escravos embarcados na capital de Angola (Ferreira, 2001, p. 349-350). Este mesmo autor informa a seguinte equivalência nas trocas no interior de Angola, mais precisamente, na feira de Kassanje: 7 litros aguardente $=$ um escravo de excelente qualidade $=5$ armas portuguesas $=15$ unidades de tecidos asiáticos ${ }^{26}$

O terceiro produto colonial que entrou na cadeia mercantil do açúcar ao ser usado para a compra de escravos foi o fumo, que de $1675 \mathrm{em}$ diante foi o principal produto no comércio bilateral entre a Bahia e o Golfo da Guiné (Alencastro, 2000, p. 323), mas que segundo Curto (2004) não era relevante no tráfico com Angola. No mesmo sentido, afirma Ferreira (2001) que foi por saberem tirar vantagem dos fumos que os baianos conseguiram controlar o tráfico de escravos saídos daquela região. Alpern (1995, p. 26) afirma que, ao tratar as folhas do tabaco com melado para evitar que ficassem ressecadas, os baianos deram ao fumo um sabor que encantou os africanos da "Costa do Ouro e especialmente da Costa dos Escravos, onde o fumo brasileiro se tornou a mercadoria mais procurada depois das conchas", obrigando ingleses, franceses e holandeses a comprar o produto baiano através dos portugueses. Sem negar a forte presença do fumo, Acioli e Menz (2008, p. 59) relativizam seu peso nas trocas por escravos. Argumentam que

apesar dos manifestos de carga das embarcações saídas da capital do Brasil ou do porto do Recife registrarem apenas rolos de tabaco, alguns testemunhos coevos atestam que não era possível aos traficantes adquirirem os escravos de sua lotação munidos apenas do tabaco de terceira (o único permitido pela Coroa naquela rota).

Estes autores apresentam documentos que relacionam os produtos levados por uma embarcação que partiu de Recife em direção à Costa da Mina: aguardente

(26) A unidade é o "kizambo", palavra que na língua kimbundo designa a quantidade de pano necessária para vestir uma pessoa (Ferreira, 2001, p. 350). 
de cana, açúcar, ouro lavrado e em pó, couros de onça, curtidos e em cabelo, redes, chapéus de sol de seda, rabos de boi, facas de ponta com cabo de tartaruga, fazenda branca da Europa e da Índia e [...] alguma seda ligeira. ${ }^{27}$

Por último, cabe observar que no século XVIII o charque aparece em maior quantidade entre os alimentos produzidos no Brasil, em parte por iniciativa da Companhia Geral do Grão Pará e Maranhão, que o importava do Brasil junto com outros alimentos que eram estocados nos portos de embarque africanos, onde se concentravam e permaneciam por dias os emigrantes forçados (Alencastro, 2000 , p. 254). ${ }^{28}$

Esta breve descrição dos produtos coloniais intercambiados por escravos mostra o quanto todos estavam atrelados ao açúcar, a mercadoria que na ponta da cadeia funcionava como a locomotiva que movimentava as atividades econômicas locais. Ainda que incipientes, estas conexões podem ser uma boa pista para os estudos que, segundo Schwartz (1992), ainda precisam ser feitos sobre a relação entre a produção para os mercados internos e externos. Em todo caso, sua hipótese é que "historicamente, a agricultura para exportação e para o consumo interno estiveram intimamentre relacionadas de uma maneira complexa, multidimensional e historicamente mutável" (Schwartz, 1992, p. 66).

Mas os encadementos para trás gerados pela necessidade de retirar de suas comunidades e enviar para a colônia portuguesa milhares de seres humanos, extenderam-se para a Europa e para a Ásia. As evidências destes encadeamentos serão apresentadas em seguida.

\section{A Ásia}

Uma forma indireta de ligação da colônia portuguesa americana com o Oriente era o abastecimento dos navios que faziam o percurso Índia-Lisboa. Lapa (1968) mostra que desde o século XVI Salvador já era um importante porto de escala para as naus da Índia, como eram conhecidas as embarcações que faziam a rota entre Portugal e as feitorias de Goa, Diu e Damião. Um indicador da relevância desta função de entreposto foi a proibição, pela Coroa, em 1565, do exercício desta intermediação, o que não a interrompeu. No século XVII foram editados outros alvarás com o mesmo fim, até que em 1672 o comércio foi aceito. Lapa destaca a importância desta medida:

O próprio tráfico de escravos, particularmente de Angola para a Bahia, passou a contar no século XVII com as embarcações do roteiro oriental que da

(27) Informação Geral da Capitania de Pernambuco. [1749]. Annaes da Bibliotheca Nacional do Rio de Janeiro, v. XXVIII, p. 482-483, 1906 apud Acioli e Menz (2008, p. 59).

(28) Alencastro observa que numa segunda etapa a mandioca e o milho passaram a ser cultivados na África, estimulando ainda mais a escravização naquele território. 
Pedro Antonio Vieira

África recebiam a carga humana, destinada ao Brasil, onde recolhiam o tabaco, tanto para os portos africanos, quanto para os asiáticos. Houve assim, articulação comercial entre os três continentes, através dos domínios lusitanos, o que estava impedido enquanto a escala no Salvador foi defesa (Lapa, 1968, p. 255, grifo nosso).

A diminuição das exportações orientais era assim compensada pelas mercadorias trazidas e levadas a Salvador, que se tornou um centro de reexportação de artigos asiáticos para todo o Atlântico Sul. Da cidade baiana os tecidos iriam diretamente para Luanda (ou, através dos traficantes, de Recife e do Rio de Janeiro). A função de entreposto foi se ampliando ao ponto de nenhum navio ter partido de Portugal para Goa em 1768 (Lapa, 1968). Os tecidos eram usados por todos os que pretendiam comprar escravos, razão pela qual também os holandeses os utilizavam nas suas transações na costa de Loango (Ferreira, 2001). A partir dos registros de algumas viagens realizadas por navios da Companhia das Índias Ocidentais ${ }^{29}$ durante o século XVII, Postma (1990) constata que os têxteis eram dominantes, que a maioria era de fabricação holandesa e que havia também artigos asiáticos exóticos muito apreciados no mercado africano. Já nos navios da Middelburgsche Commercie Compagnie, os têxteis representavam 57\% dos produtos e $50 \%$ destes tecidos provinham da Ásia. A presença dos tecidos asiáticos aumentou no decorrer do século, o que significa uma diminuição relativa dos congêneres europeus. $\mathrm{O}$ autor também registra que os tecidos eram mais usados no comércio com Loango do que com a Costa da Guiné.

Ferreira (2001, p. 356) registra ainda que provinham do Oriente $90 \%$ dos tecidos de algodão saídos de Portugal com destino ao Brasil. Lapa (1968, p. 277) constata a existência de "uma espécie de comércio triangular Brasil-ÁfricaOriente, sem grande interferência de Portugal, e com variações como OrienteBrasil-América Espanhola." Neste roteiro, a carga vinha do Oriente até Angola de onde era trazida ao Brasil junto com os escravos. Este "comércio de tabela" (Lapa, 1968) foi proibido pelo alvará de 19/6/1772, que tentava impedir transações diretas entre as colônias.

Em suma, podemos concluir que junto com a cachaça e as armas de fogo, os tecidos eram um componente indispensável do pacote de mercadorias trocadas por escravos. "Sua associação com o tráfico era tão forte que eram conhecidos como fazendas de negros." (Ferreira, 2001, p. 351, grifo do autor). O próprio Ferreira mostra a extensão espacial da cadeia mercantil do açúcar quando constata que "sob o comando dos negociantes do Brasil, o comércio de panos asiáticos interligou diferentes áreas do Império português - Brasil, África e Ásia" (Ferreira, 2001, p. 345, grifo nosso).

(29) Desde sua criação em 1621 até 1730 esta Companhia teve o monopólio do tráfico (Postma, 1990, p. 17). 


\section{A Europa}

Embora, segundo Postma (1990), desde 1593 houvesse um comercio regular entre Holanda e a costa ocidental africana, e que em 1612 fosse instalada a primeira feitoria na Costa do Ouro, nesta fase o artigo mais procurado pelos holandeses era o ouro, e não os escravos. Foi após a ocupação de Recife pela Cia. das Índias Ocidentais (CIO) em $1630^{30}$ que os holandeses perceberem que a produção do açúcar estava assentada sobre o trabalho escravo. Para garantir o suprimento da força de trabalho dos africanos, a CIO se envolveu diretamente no tráfico e foi esse envolvimento que a levou a conquistar o forte de São Jorge da Mina, na Guiné (Puntoni, 1999, p. 102). Baseado em documentos do Arquivo Geral Ultramarino, Ferreira (2001, p. 367) afirma que, nas décadas finais do século XVIII, o controle holandês era tão grande na Costa da Mina que para negociar escravos aí, os comerciantes baianos precisam pagar uma licença equivalente a $10 \%$ do valor das mercadorias que seriam trocadas por cativos. ${ }^{31}$ Nem isso os portugueses podiam fazer, pois para comprar escravos deviam usar navios brasileiros. Como resultado desta prática, os holandeses "se tornaram distribuidores das principais mercadorias do tráfico da Costa da Mina - o açúcar e o tabaco brasileiros", além do ouro que ilegalmente os comerciantes brasileiros usavam para comprar escravos (Ferreira, 2001, p. 368).

Os ingleses entraram no tráfico na segunda metade do século XVIII e os franceses o fizeram mais para o fim do século. Em menor escala, dinamarqueses, suecos e alemães também entraram para este negócio (Postma, 1990, p. 26).

$\mathrm{Na}$ segunda metade do século XVIII, os ingleses se juntaram aos holandeses e montaram "a maior carreira escravista do século XVIII" (Acioli; Menz, 2008, p. 57), aliando-se aos espanhóis para comprar escravos na África e vendê-los na América Espanhola. ${ }^{32}$ Esta maior presença de traficantes do Norte da Europa se reflete na composição das mercadorias levadas à África em troca de escravos. Como se vê na Tabela 1, nas décadas finais do século XVIII predominaram produtos europeus e asiáticos.

(30) Esta ocupação, que foi uma medida de força dos holandeses para recuperar a posição que tinham perdido na cadeia mercantil do açúcar desde que a Espanha submeteu Portugal em 1580, é vista por Postma (1990) como um desobramento lógico do envolvimento que, desde o final do século XVI, os holandeses tinham com o açúcar produzido no Brasil. A ocupação mostra também como a cadeia mercantil está imersa no contexto geopolítico.

(31) Para evitar este custo extraordinário os comerciantes baianos recorriam à proteção inglesa e navegavam com bandeira deste país. Ferreira não faz referência ao custo desta proteção.

(32) "A sociedade começou em 1752 e previa o envio de 3 mil escravos por triênio para Buenos Aires." Os ingleses levavam os escravos até a ilha de São Tomé, que pertencia a Portugal. Navios espanhóis se encarregavam de fazê-los chegar ao destino final (Ferreira, 2001, p. 371). 
Tabela 1

Origem das mercadorias importadas por Luanda

\begin{tabular}{l|c|c|c|c|c}
\hline & $1785-1797$ & $1795-1797$ & $1798-1799$ & $1802-1803$ & $1808-1809$ \\
\hline Europa & $44 \%$ & $41 \%$ & $40 \%$ & $49 \%$ & $33 \%$ \\
\hline Brasil & $22 \%$ & $31 \%$ & $18 \%$ & $16 \%$ & $28 \%$ \\
\hline Ásia & $34 \%$ & $28 \%$ & $42 \%$ & $35 \%$ & $39 \%$ \\
\hline
\end{tabular}

Fonte: Acioli e Menz (2008, p. 54).

Destarte, no período que vai de 1785 a 1809 as mercadorias europeias têm maior peso em dezessete anos, contra quatro anos dos produtos asiáticos. Já os produtos brasileiros têm menor participação em todos os anos, superando os asiáticos apenas em três anos. Quanto à composição, destacavam-se "os têxteis portugueses e ingleses, as ferragens e os armamentos do noroeste europeus" (Acioli; Menz, 2008, p. 54). Como os traficantes portugueses e brasileiros concorriam com os demais traficantes europeus, tinham que oferecer os produtos desejados pelos fornecedores de escravos. Como já vimos, a Ásia entrava com os tecidos,

enquanto a Europa Ocidental fornecia os lanifícios, as armas e utensílios metálicos. O tráfico da maior carreira escravista do séc. XVIII, a inglesa, abastecia-se de têxteis por meio da East India Company e das fontes europeias. No entanto, a parte das manufaturas importadas nas re-exportações inglesas para a África atlântica recuou continuamente desde meados do Setecentos. Primeiramente em lanifícios e, crescentemente, nos algodões e armas, a Inglaterra passou a contar com fontes internas de manufaturados, substituindo as importações e re-exportações paulatinamente ao longo do século (Acioli; Menz, 2008, p. 57).

Além desta participação direta, as mercadorias europeias chegavam à África através dos traficantes brasileiros, pois não era possível obter escravos sem oferecer mercadorias europeias e asiáticas.

\subsection{Encadeamentos espaciais devidos à procedência dos instrumentos e equipamentos empregados nas várias etapas do processo produtivo}

Nesta subseção relacionaremos e identificaremos a procedência espacial dos instrumentos de trabalho utilizados nas várias etapas em que se pode dividir a produção do açúcar: plantio, colheita e transporte da cana-de-açúcar, sua transformação em açúcar e o transporte deste até o porto. Para tanto, nos basearemos principalmente em André João Antonil, que na virada do século XVII observou e descreveu detalhamente a produção do açúcar - do plantio da cana à embalagem - tal como era realizada no Engenho Sergipe do Conde. ${ }^{33}$ Seja nos permitido comentar que o interesse de Antonil por todos os elementos do processo de trabalho - força de trabalho, meios de trabalho e objeto de trabalho - e pela

(33) Sobre este engenho, ver o Apêndice A em Schwartz (1988). 
relação entre eles é comparável aos de Marx no Livro I de "O Capital". Tal interesse não deixa de ser algo extraordinário numa época em que o trabalho, vale dizer, o esforço físico, não tinha o prestígio social da época de Marx.

\section{Plantio, colheita e transporte da cana-de-açúcar até o engenho}

Realizadas nas terras do engenho ou nas propriedades dos "lavradores de cana", as atividades de plantio e colheira da cana-de-açúcar eram realizadas por trabalhadores escravos que empregavam basicamente machados, foices e enchadas (para o desmatamento e limpeza do terreno e da roças) e facões - ou foice, na descrição de Antonil - para o corte da cana. Feitos de ferro, estes instrumentos eram importados. Após ser cortada, a cana era transportada para o engenho em barcos ou em carros de boi, os quais eram fabricados com madeira da própria região, mas com a utilização de pregos e ferramentas importadas. $\mathrm{O}$ tecido das velas dos barcos era importado e também o alcatrão com que eram vedados.

\section{Fabricação, embalagem e transporte (até o porto) do açúcar}

Ao descrever as instalações e equipamentos da casa moenda do Engenho Sergipe do Conde, Antonil (1982) menciona o uso do ferro em chapas (para revestimento), em peças (argolas, cavilhas) e componentes. Os eixos da moenda que espremiam a cana eram também revestidos de chapas de ferro. $\mathrm{O}$ caldo era depositado em um parol, "donde se guinda com dous caldeirões ou cubos para cima, com roda, eixo e correntes, e vai para outro parol" (Antonil, 1982, p. 41, grifo do autor).

Na preparação da decoada, que era uma água preparada com cinza para ajudar na purificação do caldo, usavam-se rodos e pás de ferro, além de dois tachos grandes, provavelmente de ferro ou cobre.

Antonil usa a expressão "ordem de cobre" para se referir ao seguinte conjunto de equipamentos: [além do parol do caldo e do parol da guinda, que ficam na casa da moenda] duas caldeiras (...) um parol da escuma, um parol grande (...) outro menor (...), um terno de tachas, que são quatro, a saber: a de receber, a da porta, a de cozer e a de bater; e, finalmente, uma bacia, que serve para repartir o açúcar nas formas. E (...) outros tantos cobres de igual ou pouco menor grandeza, consta outro andar semelhante. (...) Na casa das caldeiras, além destes equipamentos, há também "outros grandes vasos de cobre, como são paróis, bacias e tachas" (Antonil, 1982, p. 44), um jogo em serviço e outro sendo reparado. O autor calcula que, ao todo, o Engenho Sergipe do Conde utiliza nestes equipamentos cento e setenta e cinco arrobas ou dois mil quatrocentos e setenta e cinco kilos de cobre. 
Pedro Antonio Vieira

Não é pequena a variedade de instrumentos usados nas caldeiras:

escumadeiras, pombas (que é um vaso côncavo de cobre, com seu pau de cobre comprido doze ou quinze palmos) reminhóis, cubos, passadeiras (de cobre, é do feitio de uma pomba pequena), repartideiras, tachos, vasculhos, batedeiras (que é semlhante à escumadeira, mas com seu beiço e sem furos) bicas, cavadores, espátulas e picadeiras (Antonil, 1982 p. 46).

$\mathrm{Na}$ casa de purgar - como é chamado o processo de purificar e branquear o açúcar barreando-o, ou seja, fazendo escorrer por ele barro mole ${ }^{34}$ - o melado é depositado em formas de barro em formas de sino, que na parte mais estreita apresenta furos, por onde vai escorrer parte do conteúdo. Estas formas são fabricadas no próprio engenho ou em alguma olaria próxima. Na casa de purgar são usados os seguintres instrumentos:

furadores de ferro (...), cavadores também de ferro (...) e macetes, para o entaipar. (...) facões e machadinhos para mascavar, e de toletes, para quebrar o açúcar mascavado. No balcão de secar são necessários facões, toletes e rodos e o pau quebrador de quatro lados de costa para quebrar os pães de açúcar (Antonil, 1982, p. 50)

O combustível para cozinhar o caldo e transformá-lo em melado era a lenha, cujo "suprimento (...) para as fornalhas era tão importante quanto o de cana para o engenho" (Schwartz, 1988, p. 190) e já em 1660 surgem as primeiras constatações da sua escassez. Em seu corte são empregados foices e machados e, no transporte, barcos ou carros de boi. Segundo Schwartz (1988, p. 110), para processar dezoito cargas de cana eram consumidas oito cargas de lenha. No engenho Sergipe do Conde, todo ano eram importadas 1200 varas de tecidos para as velas dos barcos, aos quais aplicava-se alcatrão duas vezes ao ano. Cinquenta varas de pano de tenda eram necessarias para secar o açúcar, que também consumia duzentas varas de filtro (Mauro, 1997, p. 281 e seguintes).

No Engenho do Sergipe do Conde, Antonil encontrou "balanças grandes e pesos de duas arrobas e outros menores" (Antonil, 1982, p. 53).

O açúcar era acondicionado em caixas feitas com tábuas que vinham "da serraria já serradas" (Antonil, 1982, p. 43). Na fabricação das caixas usavam-se "verruma, pregos e martelo e gastalho ou gato (...) Leva uma caixa oitenta e seis pregos" e, uma vez fechadas, utilizava-se "ferro ardente ou com tinta" para estampar nas caixas o peso, o tipo de açúcar, as iniciais do engenho e as do comprador (p. 54).

(34) Que o barro, que todos consideramos algo sujo, seja purificador, não deixa de impressionar o próprio Antonil: "Nem carece de admiraração o ser o barro, que da sua natureza é imundo, instrumento de purgar o açúcar com suas lavagens, assim como a lembrança do nosso barro, e com as lágrimas se purificam e branqueiam as almas, que antes eram imundas" (Antonil, 1982, p. 52). 
Ainda de acordo com Antonil (1982, p. 55), nos engenhos à beira-mar as caixas eram levadas até o porto em pequenas carretas especiais, mais baixas, e que eram puxadas pelos escravos. Já dos engenhos longes do porto, o açúcar era trazido em carros puxados por três ou quatro juntas de bois.

Além desses encadeamentos provocados pelos insumos, o engenho, como observa Ferlini (2003, p. 136), demanda outros serviços de apoio como carpintaria, marcenaria, casas de farinha e criação de gado para corte e transporte. Carpintaria, serraria e marcenaria implicam pelo menos "os instrumentos mais usuais, a saber, serras, trados, verrumas, compassos, regras, escopros, enxós, goivas, machados, martelos, cantis e junteiras, pregos e plainas" (Antonil, 1982, p. 24).

Celso Furtado (1995) afirma que uma das consequências da produção de açúcar nas Ilhas Atlânticas foi o surgimento, em Portugal, de uma indústria produtora de equipamentos para os engenhos açucareiros. De lá vieram provavelmente todos os engenhos instalados na colônia, até que se dispusesse, aqui, de força de trabalho, ferramentas e materiais necessários à fabricação dos componentes de um engenho. Não sabemos quando esta condição foi atingida.

Por último, duas anotações para futura pesquisa. Sem especificar desde quando, Gama (1983, p. 296) afirma que na colônia já havia "moendas horizontais importadas". Já Fragoso (1998, p. 100), através das balanças comerciais de 17961811, concluiu que a plantation importava "máquinas, ferro e breu". É razoável deduzir que, com exceção das máquinas, assim também ocorria nos séculos anteriores.

\subsection{Transporte para Europa, refino e consumo}

Por definição, a cadeia de toda mercadoria se inicia na produção dos insumos (matérias-primas, equipamentos, força de trabalho, entre outros) e termina no consumo. No caso do açúcar, uma das atividades mais importantes foi o transporte da colônia para a Europa - onde seria benificiado e cosumido.

Nesta etapa de nossa pesquisa, pouco temos a dizer sobre o transporte. Apenas recordaremos que, no âmbito do exclusivo colonial, todo açucar produzido na colônia deveria ser levado para Portugal para ser então reexportado em navios portugueses, quando isso fosse possível. Pelos menos asssim mandava uma lei datada de 3 de novembro de 1571. Como a Coroa Portuguesa nunca teve meios para impor esta lei, o açúcar era transportado em navios pertencentes a comerciantes de várias nacionalidades, licenciados (genoveses, alemães de Lübeck ou de Hamburgo, ingleses, holandeses) ou não, como no caso do contrabando, frequentemente praticado por franceses, holandeses e ingleses (Mauro, 1997). 
Segundo Postma (1990, p. 14), “por volta de 1622, os estaleiros holandeses estavam construindo anualmente quinze navios somante para comercio com o Brasil." A posição de Lisboa como centro reexportador e dos comerciantes do norte como tansportadores vinha desde o século anterior, pois o "açúcar da Madeira (...), frequentente era transportado em navios dos Países Baixos." (Harreld, 2003, p. 151). Em resumo, vamos considerar que o açucar era transportado por navios e tripulações europeias.

Quanto ao refino, embora não tenhamos ainda consultado algum estudo específico e especializado, pudemos avançar recolhendo informações de várias fontes, segundo as quais o refino do açúcar da colônia portuguesa era realizado na Europa do Norte. O estudo das causas e das consequências desta divisão do trabalho entre Portugal e seus clientes não cabe nos limites deste artigo. Por agora é suficiente sabermos que desde o século XIV os interesses dos capitalistas genoveses e venezianos foram decisivos para que a divisão do trabalho entre a cidade e o campo fosse adotada na cadeia mercantil do açúcar:

A manufatura do açúcar divide-se, já na Itália do século XIV, em duas frações uma é a manufatura rural de fabricação, disseminada em grande número de pequenas unidades; a outra é a manufatura de refinação, com menor número de unidades, instaladas nas cidades e vinculadas ao grande comércio nacional e internacional (Gama, 1983, p. 322).

Esta separação entre fabricação e refino proporciona "o controle das quantidades e da qualidade do produto final e, portanto, em grande parte, do seu valor." (Gama, 1983, p. 317). Galloway (1980, p. 40) registra que "depois de 1470 importadores europeus começaram a construir refinarias, primeiro em Veneza e Bolonha, depois em Antuérpia e durante o século XVI em muitas cidades do norte da Europa, para melhorar a qualidade do açúcar." Como desde o início a fabricação de açúcar na colônia americana se realizaria de acordo com os conhecimentos e critérios técnicos, gerenciais e comerciais da época, aquela divisão espacial do trabalho, que vedava o refino à colônia, foi "naturalmente" aplicada, só que não mais sob a preeminência dos italianos:

A partir de meados do século XVI, precisamente quando se caracteriza a abertura do ciclo do açúcar, há uma clara identificação de interesses comuns entre portugueses e flamengos, que iriam dali por diante aumentando. Os lusitanos se encarregavam da etapa produtiva, os flamengos recolhiam o produto bruto em Lisboa, refinavam-no e faziam a distribuição pela Europa particularmente para o Báltico, a França e Inglaterra (Deer, 1949/1950 apud Gama, 1983, p. 312, grifo nosso).

Como vimos na observação de Galloway, esta relação vem do século XV e permaneceu quando no final do século XVI Amsterdã substituiu Antuérpia. Gama ressalta a hierarquia econômico-política da relação entre Portugal e Holanda: 
Desde o século XVI, porém, as refinarias holandesas trabalhavam com produto brasileiro, que tramitava por Portugal rumo à Antuérpia e posteriormente Amsterdã. (...) Do lado de cá interessaria a exportação do produto melhor acabado, tendo, portanto, maior valor agregado. Do lado metropolitano - a Holanda era a metrópole indireta da economia açucareira brasileira - interessaria importar açúcar bruto. Quanto mais próximo do produto natural, da matéria-prima, mais conveniente seria (Gama, 1983, p. 23).

Ora, os refinadores tinham todo o interesse em que não houvesse interrupção no fluxo de matéria-prima para suas indústrias. Com base em Stols (1973), Puntoni (1999) informa que a anexação de Portugal pela Espanha em 1580 "de início não ameaçou a posição de uma elite de mercadores envolvidos neste tipo de trato" e que "os holandeses controlavam, de forma quase absoluta a indústria do refino de açúcar e, portanto, se esforçavam para fazer o mesmo com seu comércio." De fato, continua o autor, "Amsterdã iria suceder a Antuérpia na primazia do comércio e refino do açúcar." (Puntoni, 1999, p. 32). A cronologia desta transição é a seguinte: em 1585, é montada a primeira refinaria em Amsterdã. Em 1594, eram 3. Em 1620, 25. Em 1621, 29. (25 em Amsterdã, 2 em Midelburgo, 1 em Delft e 1 em Wormer). ${ }^{35}$ Schwartz (1988, p. 146) informa que em 1650 eram 50 refinarias e em 1770, 110. Na Inglaterra, a primeira refinaria foi instalada em 1544, mas a indústria só adquiriu relevância na segunda metade do século XVII, quando o Estado, a partir de 1650, adotou medidas para direcionar para a metrópole os produtos coloniais, incluindo o açúcar bruto que seria refinado na Inglaterra. Sheridan (1973, p. 42) diz que a Lei de Navegação de 1660, no que se refere ao açúcar, "pretendia elevar os lucros da classe média, estimular refinarias domésticas e incrementar as receitas dos transportadores e do estado." As políticas mercantilistas parecem ter funcionado, pois em 1695 já havia 30 refinarias e por volta de 1753 estavavam em funcionamento 120 destes estabelecimentos, 80 dos quais em Londres, 20 em Bristol e 20 na Escócia. Esta indústria, se dizia, envolvia diretamente 1.800 trabalhadores (Sheridan, 1973, p. 29-30).

O controle sobre o refino permitiu aos holandeses e aos ingleses desenvolverem as técnicas que depois foram transferidas para a fabricação, o que por sua vez os colocou na vanguarda do desenvolvimento tecnológico da produção açucareira (Gama, 1983), posição privilegiada na cadeia mercantil do açúcar.

A decisão de reservar à colônia a função de produtora da cana e das qualidades inferiores de açúcar trazia vantagens imediatas à Coroa Portuguesa e a todos os que na colônia comandavam negócios inseridos na cadeia mercantil do

(35) Estes dados são de Puntoni (1999) que os extraiu de Deer (1949) e também de Mello (1990), "Gente da Nação", Recife; o qual por sua vez os retirou de Ijzeman, J. W. (1918) "Jounael van der Reis naar ZuidAmerika door hendrik Ottsen", Haia. 
açúcar. ${ }^{36}$ Posteriormente, quando se alteraram as condições do mercado mundial, aumentando a preferência pelo açúcar refinado, vieram à tona os inconvenientes desta posição periférica e a imperiosidade de transitar para nódulos mais rentáveis da cadeia. Em 1687, João Peixoto Viegas sugere a El Rei que, para afrontar a queda da renda proveniente do açúcar, este deveria ser refinado na colônia:

Poderá ajudar contra os açúcares das Barbadas, e Índias, mandar S.Magestade que não vam a Portugal os batidos, e mascavados, que são adubo preciso para o refino daqueles do norte, porque são fracos no doce, e os do Brasil requintam melhor neles, os mascavados mais que os brancos; e para aproveitarem no Brasil os mascavados mandar S.Mag. que se refinem cá que a isso acodirão logo oficiais desta mecânica, e armadores deste negócio como têm os estrangeiros (apud Gama, 1983, p. 314, grifo nosso).

A esta altura Portugal já não dispunha da força suficiente para mudar sua posição na divisão internacional do trabalho, sendo empurrado cada vez mais para a periferia do sistema mundial. ${ }^{37}$

Como não houve uma resposta avançada para a concorrência da produção antilhana já "atrelada à nascente indústria europeia da refinação", 38 os produtores brasileiros reagiram aumentando a exportação de produtos ainda menos elaborados. Pelo menos assim é que Gama (1983) interpreta a exportação de 10.500 de melado baiano em 1775. Feita esta breve exposição sobre o refino, podemos passar à ultima etapa da cadeia mercantil do açúcar, o consumo.

Como nosso objetivo é localizar geograficamente o consumo, não temos necessidade de estudar o consumo final. Por isso nos limitaremos a apontar as princiapis praças importadoras.

Podemos dizer que, fora o consumo interno, todo o acúcar da colônia americana era exportado para a Europa, como já acontecia com a produção de outros domínios portugueses. Alertanto que não existem números precisos para o século XVI, Harreld (2003) estima que por volta de 1560 Portugal estava importando anualmente mais ou menos 5000 toneladas de açúcar, enquanto na

(36) "O Brasil tornou-se famoso por seu açúcar "barrreado", que resultava em açúcares brancos de qualidade superior, e no pardacento e inferior mascavado. Ambos os tipos eram apropriados para o consumo imediato." No século XVI, avalia Schwartz (1988, p. 145-146), a produção do açúcar barreado atendia "o mercado lisboeta, menos complexo que o de outras cidades europeias" e talvez justificasse a ausência de refinaria. Depois esta mesma ausência reforçou a especialização no produto inferior. O pardacento, que não era exportado, passou a sê-lo como matéria-prima para as refinarias europeias.

(37) “A refinação do açúcar permanece em meio a um mistério, em segredo de ofício, meio alquímica (os misteres são mistérios zelosamente guardados) até meados do século XVIII, quando veio à luz " $L$ 'art de raffiner le sucre",o primeiro trabalho sobre tecnologia da refinação, escrito por Duhamel DuMonceau" (Gama, 1983, p. 247). No Brasil, informa este autor, na obra "Novo methodo de fazer o açúcar", editado em Salvador em 1816, Manuel Jacinto de Sampaio e Mello propunha um método de refino (Gama, 1983, p. 295).

(38) Gama (1983) aceita a informação de que a primeira refinaria em território brasileiro teria sido instalada em Santos na segunda década do século XIX. 
década de 1570 o volume médio anualmente importado teria caido para 3.300 toneladas. Através de comerciantes alemães e de Antuérpia, "grandes quantidades do açúcar atlântico era despachado para centros de comércio como Nuremberg, Frankfurt e Colônia e mesmo praças mais longínquas como Leipzig" (Harreld, 2003, p. 154), sendo esta última cidade a porta de saída para os mercados mais ao leste da Europa.

Portanto, através de Antuérpia o açúcar produzido nos domínios portugueses do Atântico alcançava o centro, o norte e o leste da Europa. Adicionalmente, o açúcar da Madeira também era exportado para Veneza, ChiosConstantinopla, Gênova e Londres (Godinho, 1983, p. 84). Não devemos olvidar que a própria Metrópole era também consumidora deste produto.

Esta situação não deve ter mudado quando, na segunda metade do século XVI, a colônia portuguesa na América se tornou a principal fornecedora de açúcar para Antuérpia.

Ferlini (2003) informa que, em 1654, dos engenhos situados entre o cabo de São Roque e o recôncavo baiano saíam 75\% das 1.200 .222 arrobas anuais produzidas no Brasil, e que essa região atendia o mercado europeu, que assim recebia, no mínimo, $75 \%$ do açúcar aqui produzido. Baseada nos dados de reexportação da alfândega do Porto - pois os dados de Lisboa foram tragados pelo terremoto de 1755 -, Costa $(2004$, p. 6) afirma que nas décadas de 1640 e 50 "Inglaterra se tornou o principal mercado, consumindo sozinha mais de $40 \%$ do açúcar re-exportado," proeminência que talvez se deva à ausência de dados das reexportações para Itália, provavelmente do Porto. Embora fosse o maior mercado da Europa, a partir de 1660 o Reino Unido importava cada vez mais de suas colônias. No final do século XVII, quando as coffee houses s espalharam por Londres, o açúcar passou a ser necessário para adequar o café, o chá e o chocolate ao gosto dos ingleses, e acompanhando esses produtos, o consumo de açúcar per capita passou de cerca de duas libras em 1660 para aproximadamente vinte em 1795 (Ashworth, 2003, p. 231). Sheridan (1973, p. 21) afirma que entre 1663 e 1775 o consumo aumentou vinte vezes na Inglaterra e em Gales. Ainda conforme Sheridan (1973, p. 25), "pouco se conhece dos padrões de consumo em outras partes da Europa, mas parece que, como na França, nestes países o consumo deve ser menor que na Inglaterra." Apesar disso, a França era um mercado importante, como também era a Alemanha. E à medida que Inglaterra e França aumentavam as importações de suas colônias, Portugal tinha que procurar outros mercados, mas ainda na Europa, onde a demanda poderia continuar crescendo por muito tempo, pois em 1783 somente metade da Europa conhecia este produto (Braudel, 1995, p. 200).

Quanto ao consumo na própria colônia, segundo Antonil (1982, p. 56), no final do século XVII somente $2,2 \%$ do açúcar produzido "ficavam na terra (...) 
para o gasto dela". Ainda que o crescimento populacional e a diversificação econômica provocadas pela mineração no século XVIII tenham aumentado o percentual da produção não exportada, a Europa, aí incluída a Metrópole, se manteve como principal destino da produção brasileira pelo menos até bem entrado o século XIX.

\subsection{Esboço da cadeia mercantil do açúcar}

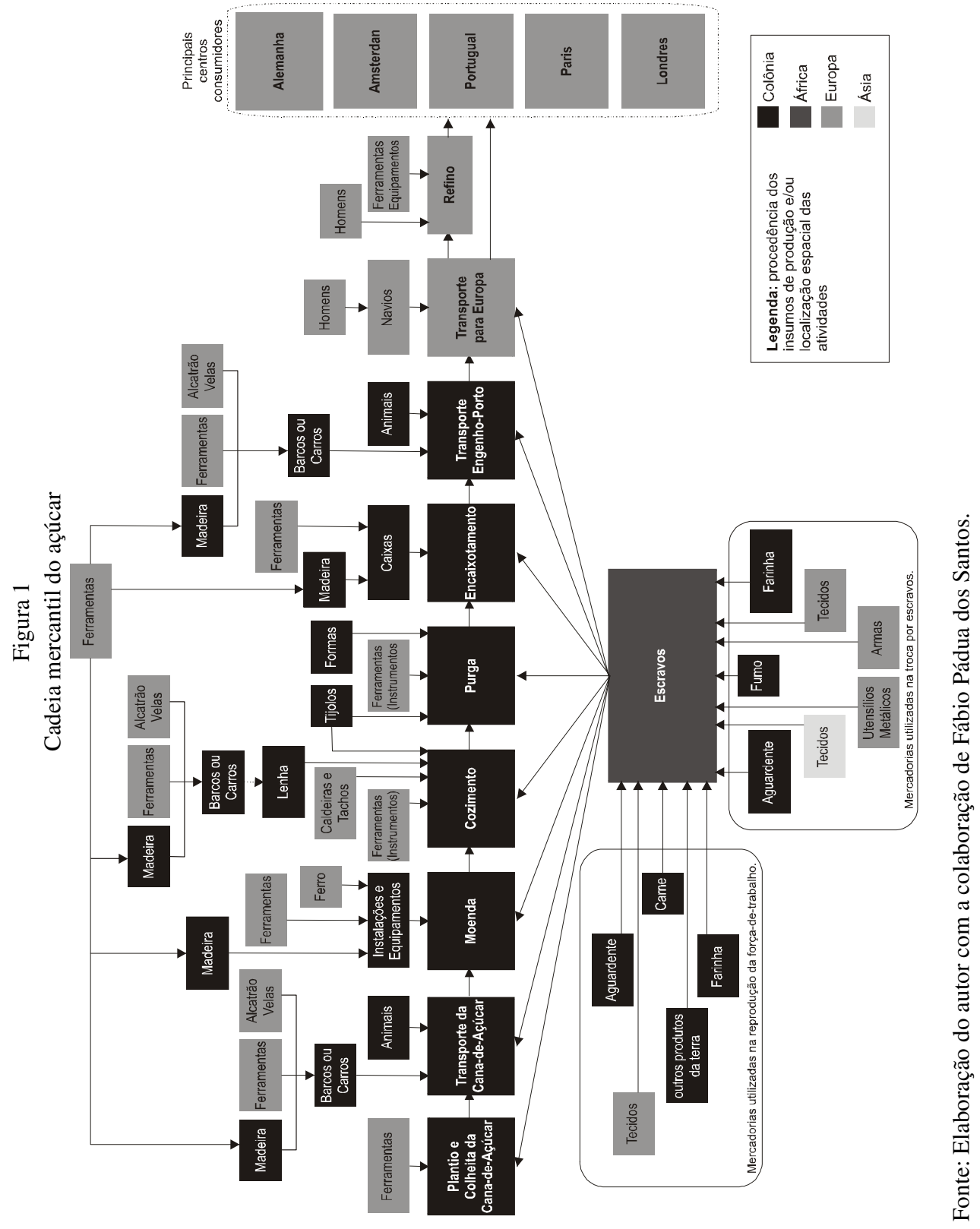


Hopkins e Wallerstein (1994) reconstituiram as cadeias mercantis do trigo e da construção naval no período 1590-1790, com o objetivo de examinar a complexidade social, o alcance espacial e as mudanças dessas cadeias. Nossa reconstrução da cadeia mercantil do açúcar, tal como apresentada na Figura 1, visa apenas ilustrar a extensão desta cadeia, através da identificação e localização espacial dos principais processos que a compõem. Assim, embora contenha o nome de um produto, cada caixa da figura representa um processo produtivo da cadeia. No centro do desenho, destacamos as etapas do processo produtivo propriamente dito que ocorrem na colônia (plantio, transporte e tranformação da cana-de-açúcar, encaixotamento e transporte do açúcar até o porto), bem como o transporte para a Europa, onde ocorriam o refino e o consumo. Acima deste eixo, inserimos os insumos que são necessários para que as anteriores atividades sejam realizadas. Ao realizar esta inserção, pudemos perceber que certos insumos, como as ferramentas, são uma condição sine qua non para a operação de um engenho, ainda que, ao contrário das caldeiras, não apareçam como tal. De fato, embora não sendo as mesmas, ferramentas são necessárias para cortar a madeira e transformála em móveis, casas, rodas d'água, eixos, moendas, mesas, barcos e carros de boi, e também para processar e encaixotar o açúcar. É por esta razão que aparecem com tanta frequência na Figura 1. Por serem de ferro, estas ferramentas eram importadas.

Na parte inferior da Figura 1 procuramos evidenciar os processos ligados ao fornecimento da força de trabalho. Abaixo da caixa escravos listamos as mercadorias usadas para conseguir os trabalhadores cativos, e à esquerda as mercadorias que garantiam a subsistência deles na colônia. Devemos ter em mente que a produção de cada uma destas mercadorias demanda insumos e força de trabalho e tem sua própria cadeia, o que capilariza ainda mais a cadeia mercantil do açúcar.

\section{Conclusão}

Neste texto, através da extensão territorial da cadeia mercantil do açúcar, tentamos estender uma ponte entre os relatos sobre o desenvolvimento do moderno sistema mundial levados a cabo por Wallerstein (1999) e Arrighi (1996), os quais deliberadamente não "descem" aos processos regionais e ou locais, e a linha de interpretação da história econômica brasileira desenvolvida por Celso Furtado, Caio Prado Júnior e seguida por Fernando Novais. Esses autores, embora não cheguem a isolar os processos regionais e locais, não os veem como concretizações ou manifestações sistêmicas, ou melhor, não se preocupam em mostrar os vínculos entre os grandes processos sistêmicos e os processos internos à terra brasilis. 
Através do conceito de cadeia mercantil vimos que as atividades implicadas na produção, comercialização e consumo do açúcar se espalhavam pela América, Europa, África e Ásia, formando uma verdadeira rede de negócios com muitas conexões, entre as quais se pode destacar:

(I) América (colônia) $\leftrightarrow$ Europa: As relações entre estas duas regiões são tão fortes e necessárias que poderíamos inclusive dizer que a cadeia mercantil começa e termina na Europa, porque é de lá que a) vem o impulso inicial para a instalação da agroindústria e muitos dos equipamentos e ferramentas indispensáveis aos vários processos de trabalho, como também alimentos e tecidos, além de armas para o escambo na África; b) lá está localizada a fase final do processo de transformação - o refino -; e c) para lá se dirige o grosso (se não a totalidade) da produção.

(II) América (colônia) $\leftrightarrow$ África: A força de trabalho, que junto com os meios de produção constituem os elementos de qualquer processo de trabalho (cf. Marx), vinha da África. Para arrancar de suas comunidades, reunir, manter e transportar os cerca de 4.029.800 homens, mulheres e crianças que, se estima, aportaram na colônia entre 1551 e 1860 (Alencastro, 2000, p. 69), foram necessários homens, equipamentos (navios e armas, entre outros), instalações (para abrigo) e mercadorias (para o escambo e manutenção em trânsito) em quantidades monumentais e que procediam dos quatros cantos da terra, incluindo a própria colônia, de onde saíam produtos locais (farinha de mandioca, cachaça e fumo, entre outros) e importados (tecidos, armas e ferramentas).

(III) América $\leftrightarrow$ África $\leftrightarrow$ Ásia: Produtos coloniais, como o fumo eram trocados na Ásia por tecidos, os quais necessariamente deviam compor a cesta de artigos intercambiados por escravos.

Além desta dimensão externa ao espaço da colônia, a cadeia mercantil do açúcar se ramificou dentro do território colonial através da produção da matériaprima, do combustível (lenha), de equipamentos e de vários tipos de insumo para produzir, embalar e transportar o açúcar. Inicialmente pequena, esta dimensão interna muito provavelmente foi crescendo à medida que se ampliava a capacidade técnica e humana instalada na colônia, tanto na agricultura como na manufatura. Se para os primeiros engenhos, os técnicos, equipamentos, certos alimentos e tecidos necessariamente eram trazidos da Europa, em algum momento posterior foi possível encontrar substitutos locais. Ao suprir as demandas da agroindústria açucareira esta "oferta ou produção interna", que Fragoso e Florentino (2001) mostram ser pujante na segunda metade do século XVIII, se tornava parte inseparável da cadeia mundial do açúcar. No caso dos alimentos, como vimos, houve sempre uma oferta local. 
Nessa primeira aproximação não pudemos ainda mostrar em detalhes os encadeamentos para trás provocados pelo processo produtivo. Não obstante, nossa descrição deste processo é suficiente para que se tenha uma ideia da quantidade e variedade das instalações, equipamentos e ferramentas empregadas em um engenho. A dificuldade de identificar os materiais utilizados impede determinar com precisão sua procedência, mas a utilização do cobre no cozimento, do ferro para cobrir parte das moendas e o emprego de grandes escumadeiras, machadões, foices, enxadas, martelos, serras, foices, pregos, enfim, de uma grande quantidade de meios de produção de ferros, são evidências muito fortes de que, também para trás, a cadeia da fabricação do açúcar se estendia firmemente para a Europa. A literatura quase sempre destaca o cobre. De fato, Mauro (1997, p. 249) relata que, na Ilha da Madeira, em 1611 a guerra impedia importar caldeiras flamengas. Os fundos das caldeiras eram refeitos a cada ano, o que consumia cerca de $136 \mathrm{~kg}$ do metal (Mauro, p. 281).

Por fim, uma palavra sobre a importância do consumo. Desde Marx, tem se desenvolvido uma forte tendência de colocar a produção - onde o valor é produzido - no ápice do processo de acumulação de capital, em detrimento do consumo, considerado quase sempre como uma etapa "passiva" neste processo. Uma visão mais abrangente, como a proporcionada pelo enfoque das cadeias mercantis globais, vai mostrar que o consumo é também fonte de inovações e de mudanças que repercutem na produção. De fato, o açúcar se transformou em um artigo de consumo corrente e cada vez mais popularizado quando, no século XVIII, passou a ser usado na fabricação de bebidas alcoólicas, sobremesas e doces, e também para tornar palatáveis o chá, o café e o chocolate. Foi esta popularização que permitiu o aumento da produção e sua difusão por várias partes do contiente americano (mas não só dele), o que por sua vez aumentava a competição, diminuia os preços e ampliava ainda mais o universo de consumidores. Estas mudanças, assim como a disseminação da indústria do refino, ocorreram naqueles "países que então prosperavam economicamente, que tinham importantes recursos de capital, trabalho livre e qualificado, países que se encontravam já no caminho do desenvolvimento" (Malowist, 1969, p. 29 apud Wallerstein, 1999, p. 172, grifo do autor).

As mudanças havidas na cadeia mercantil no período estudado, bem como suas causas e consequências - econômicas, políticas, sociais e culturais - fazem parte do nosso programa de pesquisa para os próximos anos.

\section{Referências bibliográficas}

ABU-LUGHOD, Janet L. Before European hegemony: the World-System A.D. 12501350. Oxford/New York: Oxford University Press, 1989. 
Pedro Antonio Vieira

ACIOLI, Gustavo; MENZ, Maxilimiano, M. Resgate e mercadorias: uma análise comparada do tráfico luso-brasileiro de escravos em Angola e na Costa da Mina (século XVIII). Revista Afro-Ásia da UFBA, n. 37, p. 43-73, 2008.

ALENCASTRO, Luiz F. de. O trato dos viventes: formação do Brasil no Atlântico Sul. São Paulo: Companhia das Letras, 2000.

ALPERN, Stanley B. What Africans got for their slaves: a master list of European trade goods. History in Africa, 22, p. 5-43, 1995.

ANTONIL, André J. Cultura e opulência do Brasil. 3. ed. Belo Horizonte: Itatiaia/Edusp, 1982.

ARRIGHI, Giovanni. O longo século XX: dinheiro, poder e as origens de nosso tempo. Rio de Janeiro: Contraponto; São Paulo: Editora Unesp, 1996.

ASHWORTH, William A. J. Customs and excise: trade, production and consumption in England, 1640-1845. Oxford: Oxford University Press, 2003.

BRAUDEL, Fernand. Civilização material, economia e capitalismo, séculos XV-XVIII As estruturas do cotidiano. São Paulo: Martins Fontes, 1995.

COMERLATTO, Lairton M.; LINS, Hoyêdo N. Produção moveleira em São Bento do Sul(SC): a perspectiva das cadeias globais. Ensaios FEE, Porto Alegre, v. 39, n. 2, p. 503530, s.d.

COSTA, Leonor Freire. Merchant groups in the $17^{\text {th }}$ - century Brazilian sugar circle: reappraising old topics with new research insights. e-Journal of Portuguese History, v. 2, n. 1, Summer 2004.

CURTO, José C. The Portuguese-Brazilian alcohol trade at Luanda and its Hinterland, c.1550-1830. Leinden, London: Brill, 2004.

DEER, Noel. The history of sugar. London: Chapmann and Hall, 1949/1950. 2v.

FERLINI, Vera. Terra, trabalho e poder: o mundo dos engenhos no Nordeste colonial. Bauru-SP: Edusc, 2003.

FERREIRA, Roquinaldo. Dinâmica do comércio intracolonial: Geribitas, panos asiáticos e guerra no tráfico angolano de escravos (Século XVIII). In: FRAGOSO; BICALHO e GOUVÊA (Org.). O Antigo Regime nos trópicos: a dinâmica imperial portuguesa (séculos XVI-XVIII). Rio de Janeiro: Civilização Brasileira, 2001.

FRAGOSO, João L. Homens de grossa aventura: acumulação e hierarquia na praça mercantil do Rio de Janeiro, 1790-1830. Rio de Janeiro: Civilização Brasileira, 1998.

FRANGOSO, João; FLORENTINO, Manolo. O arcaísmo como projeto: mercado atlântico, sociedade agrária e elite mercantil em uma economia colonial tardia, Rio de Janeiro, c. 1790-1840. Rio de Janeiro: Civilização Brasileira, 2001.

FURTADO, Celso. Formação econômica do Brasil. 25. ed. São Paulo: Editora Nacional, 1995.

GAMA, Ruy. Engenho e tecnologia. São Paulo: Duas cidades, 1983.

GODINHO, Vitorino M. Os descobrimentos e a economia mundial. Lisboa: Editorial Presença, 1983. v. IV.

GALLOWAY, John H. The sugar cane industry: an historical geography from Its origins to 1914. Cambridge: Cambridge University Press, 1980. 
GEREFFI, Gary; KORZENIEWICZ, Miguel (Org.). Commodity chains and global capitalism. Wesport, Connecticut and London: Greenwood Press, 1994.

GOOTENBERG, Paul. Cocaine in chains: the rise and demise of a global commodity, 1860-1950. In: TOPIK, S; MARICHAL, C.; FRANK, Z. From silver to cocaine - Latin American commodity chains and the building of the world economy, 1500-2000. Durham and London: Duke University Press, 2006.

HARRELD, Donald D. Atlantic sugar and Antwerp trade with Germany in the Sixteenth Century. Journal of Early Modern History, v. 7, n.1-2, p. 148-162, 2003.

LAPA, José Roberto do A. A Bahia e a Carreira da Índia. São Paulo: Companhia Editora Nacional, 1968.

MAURO, Frédéric. Portugal, o Brasil e o Atlântico, 1570-1670. Lisboa: Estampa, 1997. v. 1.

NOVAIS, Fernando Antonio. Aproximações: ensaios de história e historiografia. São Paulo: Cosac Naify, 2005.

POSTMA, Johannes M. The Dutch in the Atlantic Slave Trade, 1600-1815. New York, Port Chester, Melbourne and Sidney: Cambridge University Press, 1990.

PRADO JR., Caio. Formação do Brasil contemporâneo. 23. ed. São Paulo: Brasiliense, 2008.

PUNTONI, Pedro. A mísera sorte: a escravidão africana no Brasil holandês e as guerras do tráfico no Atlântico Sul, 1621-1648. São Paulo: Hucitec, 1999.

SCHWARTZ, Stuart B. Segredos internos: engenhos e escravos na sociedade colonial, 1550-1835. São Paulo: Companhia das Letras, 1988.

Slaves, peasants and rebels - Reconsidering Brazilian slavery. Urbana and Chicago: University of Illinois Press, 1992.

STOLS, Eddy. Os mercadores flamengos em Portugal e no Brasil antes das conquistas holandesas. Anais de História, Assis, 5, p. 36, 1973.

TOPIK, S; MARICHAL, C.; FRANK, Z. From silver to cocaine - Latin American commodity chains and the building of the world economy, 1500-2000. Durham and London: Duke University Press, 2006.

SHERIDAN, Richard B. Sugar and slavery - An economic history of the British West Indies, 1623-1775. Baltimore: The Johns Hopkins University Press, 1973.

WALLERSTEIN, Immanuel. El moderno sistema mundial: la agricultura capitalista y los orígenes de la economía-mundo europea en siglo XVI. México: Siglo XXI, 1999.

The capitalist world-economy. London and Paris: Cambridge University Press and Editions de la Maison des Sciences de l'Home, 1979.

; HOPKINS, Terence K. Commodity chains in the world-economy prior to 1800. In: WALLERSTEIN, Immanuel. The essential Wallerstein. New York: The New Press, 2000.

; C_ Commodity chains: construct and research. In: GEREFFI, Gary; KORZENIEWICZ, Miguel (Org.). Commodity chains and global capitalism. Westport, Connecticut and London: Greenwood Press, 1994. 